\title{
PENGARUH KUALITAS PRODUK DAN CITRA MEREK TERHADAP KEPUTUSAN PEMBELIAN KONSUMEN PADA RUMAH MAKAN SRI MELAYU DI KOTA PALEMBANG
}

\author{
Zubaidah Warni \\ Fakultas Ekonomi Universitas Palembang \\ Email: zubaidahunpal@gmail.com
}

\begin{abstract}
ABSTRAK
Keputusan pembelian adalah sebuah proses dimana konsumen mengenal masalahnya, mencari informasi mengenai produk atau merek tertentu dan mengevaluasi seberapa baik masing-masing alternatif tersebut dapat memecahkan masalahnya, yang kemudian mengarah kepada keputusan pembelian. Keputusan pembelian di pengaruhi oleh banyak faktor dan penelitian ini membahas pengaruh kualitas produk dan citra merek terhadap keputusan pembelian konsumen pada rumah makan Sri Melayu di Kota Palembang. Dari hasil uji regresi berganda di ketahui bahwa kualitas produk dan citra merek berrpengaruh positif terhadap keputusan pembelian secara parsial dengan nilai koofisien regresi sebesar 0,479 untuk kualitas produk dan 0,390 untuk citra merek. Hasil uji secara simultan untuk uji koofisien determinasi sebesar 0,606 itu berarti kualitas produk dan citra merek mampu menjelaskan perilaku konsumen pada rumah makan Sri Melayu sebesar 60,6 \% dan sisanya dipengaruhi oleh variabel lain di luar penelitian ini.
\end{abstract}

Kata Kunci: Kualitas Produk, Citra Merek, dan Keputusan Pembelian

\section{I.PENDAHULUAN}

\section{Latar Belakang Masalah}

Bisnis kuliner di kota Palembang juga mengalami perkembangan yang pesat dimana banyak bermuculan rumah makanrumah makan yang menawarkan cita rasa lokal. Ditinjau dari sisi konsumen, dapat dilihat bahwa terjadi perubahan perilaku masyarakat Palembang dalam mengkonsumsi produk makanan dan minuman khususnya di rumah makan atau restoran. Saat ini terdapat semacam trend bahwa perilaku makan dan minum di rumah makan bukan saja sekedar untuk memenuhi kebutuhan akan rasa lapar, tetapi sudah menjadi semacam gaya hidup tersendiri. Salah satu rumah makan yang menawarkan cita rasa lokal adalah rumah makan Sri Melayu, Tempat ini termasuk dalam daftar tujuan kuliner khas Palembang yang direkomendasikan banyak pecinta makanan. Selain tempatnya yang sangat nyaman, cozy, natural, bersih. Menu yang ditawarkan pun beragam dan rasanya nikmat, harganya masih terbilang cukup terjangkau meskipun sebagian memang agak mahal bagi pengunjung. Terdapat beberapa gazebo tempat makan lesehan disamping bangunan utama yang tempat duduknya menggunakan meja-kursi.Sri Melayu menawarkan konsep taman yang sejuk, letaknya juga sangat strategis karena persis bersebelahan dengan Griya Agung (Istana Gubernur) Sumatera Selatan. Sehingga masyarakat yang melintas jalan Demang Lebar Daun dengan sangat mudah menemukan tempat ini.Sri Melayu memang sudah ada sejak puluhan tahun lalu, tidak terhitung berapa banyak pejabat, tokoh dan artis yang mampir kesini. Tempat makan khas Palembang ini memang sudah dikenal banyak orang sejak dulu.

Areanya yang sangat luas, sedangkan di bagian dalam terdapat ruangan pertemuan dilantai 3 dengan full ac juga meja prasmanan. Dilantai 2 juga ada ruang pertemuan dengan konsep semi outdoor, ditengahnya terdapat kolam ikan yang besar dan air mancur. Rumah Makan 
Sri Melayu ini memang membuat suasanan makan yang asri dan rindang. Berpadu budaya dengan model bangunan berkonsepkan kayu berukiran khas Sumatera Selatan dengan corak khas melayu. Terdapat Live Musik yang dapat membuat suasana semakin nyaman, sembari makan dan bersantai disini. Adapun omset yang dimiliki oleh rumah makan Sri Melayu adalah sebagai berikut:

Tabel 1.1

Omset Penjualan Rumah Makan Sri Melayu Palembang

\begin{tabular}{|l|c|c|c|c|r|}
\hline \multirow{2}{*}{ Bulan } & \multicolumn{5}{|c|}{ TAHUN } \\
\cline { 2 - 7 } & $\mathbf{2 0 1 6}$ & $\mathbf{2 0 1 7}$ & $\mathbf{2 0 1 8}$ & $\mathbf{2 0 1 9}$ & \multicolumn{1}{c|}{$\mathbf{2 0 2 0}$} \\
\hline Januari & 564.500 .300 & 524.100 .000 & 570.120 .200 & 575.500 .600 & 470.350 .000 \\
\hline Februari & 559.400 .000 & 560.105 .000 & 559.930300 & 615.250 .300 & 435.650 .200 \\
\hline Maret & 649.900 .250 & 561.330 .000 & 461.250 .000 & 412.450 .250 & 379.670 .100 \\
\hline April & 792.300 .000 & 658.720 .000 & 660.700 .000 & 530.255 .700 & 467.800 .000 \\
\hline Mei & 560.200 .000 & 462.150 .500 & 471.100 .100 & 178.450 .200 & 310.000 .000 \\
\hline Juni & 563.150 .250 & 657.270 .000 & 665.150 .000 & 535.350 .775 & 416.350 .200 \\
\hline Juli & 611.800 .000 & 689.430 .000 & 558.650 .000 & 765.350 .250 & 576.450 .500 \\
\hline Agustus & 455.900 .000 & 560.050 .500 & 562.150 .000 & 555.650 .700 & 480.400 .200 \\
\hline September & 457.800 .300 & 459.200 .000 & 560.350 .000 & 585.530 .000 & 518.200 .450 \\
\hline Oktober & 564.050 .000 & 561.050 .000 & 557.200 .000 & 650.600 .000 & 389.250 .345 \\
\hline Nopember & 423.250 .000 & 659.600 .000 & 563.050 .000 & 598.400 .300 & 410.250 .700 \\
\hline Desember & 590.650 .400 & 545.200 .000 & 621.778 .000 & 590.550 .200 & 423.400 .200 \\
\hline jumlah & 6.792 .901 .500 & 6.898 .206 .000 & 6.911 .428 .600 & 6.993 .339 .275 & 4.867 .522 .195 \\
\hline Sumber Rum
\end{tabular}

Sumber: Rumah Makan Sri Melayu

Dari data diatas dapat dilihat perkembangan omset Rumah Makan Sri Melayu yang mengalami kenaikan setiap tahunnya, tetapi ada penurunan di tahun 2020 ini disebabkan karena adanya pandemi Corona yang sedang melanda diseluruh dunia di Indonesia dan juga di Kota Palemabng. Melihat fenomena yang ada dimana omset rumah makan yang selalu mengalami fluktuasi dalam setiap bulannya, serta strategi bauran pemasaran yang telah digunakan Rumah Makan Sri Melayu maka penulis berminat untuk melakukan penlitian dengan judul "Pengaruh Kualitas Produk dan Citra Merek terhadap Keputusan Pembelian Konsumen pada Rumah Makan Sri Melayu di Kota Palembang".

\section{Rumusan Masalah}

1. Apakah kualitas produk dan citra merek berpengaruh secara parsial dan Simultan terhadap keputusan pembelian konsumen pada rumah makan Sri Melayu di kota Palembang?

2. Apakah ada pengaruh yang dominan diantara variabel kualitas produk dan citra merek terhadap keputusan pembelian konsumen pada rumah makan Sri Melayu di kota Palembang?

\section{Tujuan Penelitian}

1. Untuk mengetahui secara parsial dan simultan pengaruh kualitas produk dan citra merek terhadap keputusan pembelian konsumen pada rumah makan Sri Melayu di kota Palembang? 
2. Untuk mengetahui pengaruh yang dominan diantara varriabel kualitas produk dan citra merek terhadap keputusan pembelian konsumen pada rumah makan Sri Melayu di kota Palembang?

\section{Manfaat Penelitian}

a. Bagi Penulis

Dapat menambah ilmu pengetahuan dan pengalaman dalam menerapkan teori yang diperoleh dengan praktek yang sesungguhnya dalam permasalahan dan dapat menambah wawasan dan pengalaman dalam memecahkan masalah secara ilmiah.

b. Bagi Perusahaan

Sebagai bahan masukan yang dapat dijadikan pertimbangan bagi perusahaan dalam menetapkan kebijaksanaan upah dan insentif yang diberikan kepada kinerja karyawan.

c. Bagi Almamater

Penelitian ini diharapkan dapat menjadi kontribusi penulis kepada lembaga Fakultas Ekonomi Universitas Palembang dan dapat dugunakan sebagai landasan bagi peneliti selanjutnya.

\section{II.TINJAUAN PUSTAKA}

\subsection{Landasan Teori}

\subsubsection{Pemasaran}

Pengertian pemasaran menurut Sofjan Assauri (2017: 5) adalah "kegiatan manusia yang diarahkan untuk memenuhi dan memuaskan kebutuhan dan keinginan melalui proses pertukaran". Menurut AMA (American Marketing Association) dalam Adisaputro (2017: 4) pemasaran adalah "fungsi organisasional dan seperangkat proses untuk menciptakan, mengkomunikasikan, dan menyerahkan nilai-nilai kepada pelanggan dan untuk mengelola hubungan pelanggan dengan cara-cara yang menguntungkan bagi organisasi dan semua pemangku kepentingan".

\subsubsection{Kualitas Produk}

Kualitas produk merupakan totalitas fitur dan karakteristik yang yang mampu memuaskan kebutuhan, yang dinyatakan maupun tidak dinyatakan, kualitas mencakup pula daya tahan produk, kehandalan, ketepatan, kemudahan operasi dan perbaikan, serta atribut-atribut nilai lainnya. Beberapa atribut itu dapat diukur secara obyektif. Dari sudut pandangan pemasaran, kualitas harus diukur sehubungan dengan persepsi kualitas para pembeli (Kotler dan Keller, 2019;; Assauri, 2017). Menurut Assauri (2017:48) mutu atau kualitas produk dipengaruhi oleh faktor yang akan menentukan bahwa mutu barang dapat memenuhi tujuannya, yaitu untuk meningkatkan minat beli konsumen. Sedangkan menurut Tjiptono (2019:99), kualitas produk dapat diklasifikasikan menjadi empat indikator yaitu:

1. Convinience Goods merupakan barang pada umumnya memiliki frekuensi pembelian tinggi/sering dibeli, dibutuhkan dalam waktu segera,dan hanya memerlukan usahayang minimum (sangat kecil) dalam pembandingan dan pembelian.

2. Shopping Goods adalah barang-barang yang dalam proses pemilihan dan pembelian dibandingkan oleh konsumen diantara berbagai alternative yang tersedia.

3. Specialty Goods adalah barang-barang yang memiliki karakteristik atau identitas merek yang unik dimana sekelompok konsumen bersedia melakukan usaha khusus untuk membelinya.

4. Unsought Goods merupakan barangbarang yang tidak diketahui konsumen atau kalaupun sudah diketahui, tetap pada umumnya belum terpikir untuk membelinya. 


\subsubsection{Citra Merek}

Menurut Tjiptono (2019:112), citra merek (brand image atau brand description) yakni deskrispi tentang asosiasi dan keyakinan konsumen terhadap merek tertentu. Sejumlah teknik kuantitatif dan kualitatif telah dikembangkan untuk membantu mengungkap persepsi dan asosiasi konsumen terhadap sebuah merek tertentu, diantaranya multi dimensional scaling, projection techniques, dan sebagainya. Menurut Susanto (dalam Farid Yuniar Nugroho, 2011:11) citra merek adalah apa yang di persepsikan oleh konsumen mengenai sebuah merek. Citra merek dibentuk melalui kepuasan konsumen, penjualan dengan sendirinya diperoleh melalui kepuasan konsumen, sebab konsumen yang puas selain akan kembali membeli, juga akan mengajak calon pembeli lainnya (Aaker dalam Farid Yuniar Nugroho, 2011:10)

\subsubsection{Keputusan pembelian}

Menurut Schiffman dan Kanuk (2010:432) 'Keputusan pembelian merupakan proses kepemimpinan pendapat dimana seseorang secara informasi mempengaruhi tindakan atau sikap orang lain, yang orang lain tersebut mungkin merupakan para pencari pendapat atau semata-mata hanya menerima pendapat". Terdapat tiga komponen utama dalam proses pengambilan keputusan konsumen. Ketiga komponen utama tersebut adalah: Input, Proses, dan Output Schiffman dan Kanuk (2010:482). Menurut Fandy Tjiptono (2019:21) 'Keputusan pembelian adalah sebuah proses dimana konsumen mengenal masalahnya, mencari informasi mengenai produk atau merek tertentu dan mengevaluasi seberapa baik masing-masing alternatif tersebut dapat memecahkan masalahnya, yang kemudian mengarah kepada keputusan pembelian”.
Keputusan pembelian adalah keputusan pembeli tentang merek mana yang dibeli (Kotler dan Amstrong, 2012:181). Pengertian lain keputusan pembelian adalahkeputusan konsumen mengenai preferensi atas merek-merek yang ada di dalamkumpulan pilihan (Kotler dan Keler,2019:240).

\subsection{Penelitian Terdahulu}

1. Penelitian Sinta Septiana (2016), dengan judul "Pengaruh citra merek dan kualitas produk terhadap keputusan pembelian konsumen pada sabun mandi cair merek Dettol di Bandar Lampung". Hasil penelitian mengungkapkan bahwa citra merek dan kualitas produk berpengaruh positif dan signifikan terhadap keputusan pembelian konsumen pada sabun mandi cair merek Dettol di Bandar Lampung.

2. Penelitian S Jordanus Saleh (2017), dengan judul "Pengaruh citra merek dan kualitas pelayanan terhadap keputusan pembelian Sepatu Merek Vans. Hasil penelitian mengungkapkan bahwa secara parsial dan simultan variabel citra merek dan kualitas produk berpengaruh terhadap keputusan pembelian Sepatu Merek Vans.

3. Eka Dessy Mardiastiorini (2028), dengan judul "Pengaruh kualitas produk dan citra merek terhadap keputusan pembelian produk Benih Jagung Bisi. Hasil penelitian mengungkapkan bahwa kualitas produk dan citra merek berpengaruh secara parsial dan simultan terhadap keputusan pembelian produk Benih Jagung Bisi 


\subsection{Kerangka Fikir}

\section{Gambar 1 \\ Kerangka Fikir Penelitian}

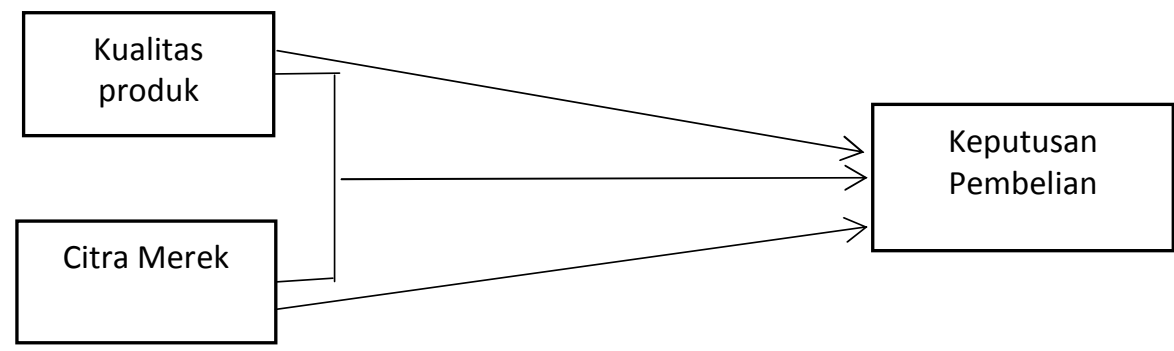

\subsection{Hipotesis}

Berdasarkan rumusan masalah dan kajian teoritis yang dikembangkan maka penulis mengajukan Hipotesis sebagai berikut:

1. Ho : Tidak terdapat pengaruh yang signifikan secara parsial dan simultan antara variabel kualitas produk, dan citra merek terhadap keputusan pembelian konsumen rumah makan Sri Melayu Palembang.

$\mathrm{Ha}$ : Terdapat pengaruh yang signifikan secara parsial dan simultan antara variabel kualitas produk dan citra merek terhadap keputusan pembelian konsumen rumah makan Sri Melayu Palembang.

2. Ho : Tidak terdapat pengaruh yang dominan antara variabel produk, harga, distribusi dan promosi terhadap keputusan pembelian konsumen rumah makan Sri Melayu Palembang.

$\mathrm{Ha}$ : Terdapat pengaruh yang dominan antara variabel kualitas produk dan citra merek terhadap keputusan pembelian konsumen rumah makan Sri Melayu Palembang.

\section{METODE PENELITIAN}

\subsection{Objek Penelitian}

Objek penelitian ini adalah Konsumen yang berlokasi di jalan Demang Lebar Daun No 24 Kota Palembang

\subsection{Ruang Lingkup Penelitian}

Dalam melakukan penelitian agar tidak menyimpang dari permasalahan yang ada maka penulis menitik beratkan pembahasan pada pengaruhkualitas produk dan citra merek terhadap keputusan pembelian konsumen rumah makan Sri Melayu Palembang

\subsection{Desain Penelitian}

Metode yang digunakan dalam penelitian ini adalah metode eksploratif, menurut Sekaran (2017:155): "Studi eksploratif (exploratory study) dilakukan jika tidak banyak yang diketahui mengenai situasi yang dihadapi, atau tidak ada informasi yang tersedia mengenai bagaimana masalah atau isupenelitian yang mirip diselesaikan di masa lalu.Menurut Sekaran (2017:66): "Mewawancara, memberikan kuesioner, dan mengobservasi orang dan fenomena adalah tiga metode pengumpulan data yang utama dalam penelitian survei."

\subsection{Jenis dan Sumber Data}

\subsubsection{Jenis Data}

Menurut Mudrajad Kuncoro (2014: 145) data adalah "sekumpulan informasi yang diperlukan untuk pengambilan keputusan". Terdapat dua jenis data yang digunakan dalam penelitian (Umar, 2014:12) yaitu:

1. Data Kualitatif

Data dalam penelitian biasanya berbentuk kata-kata, gambar dan 
sedikit angka yang dianalisis dalam terminologi respon-respon individual, kesimpulan deskriptif, atau keduanya. Biasanya data dalam bentuk skala nominal, ordinal, atau interval.

2. Data Kuantitatif

Data kuantitatif mendasarkan hasil penelitian pada perhitunganperhitungan matematis yang kemudian memberikan gambaran atas suatu fenomena kasus yang diajukan dalam penelitian. Data angka yang dihasilkan menjadi acuan atau parameter tingkat atau level yang telah ditentukan sebelumnya. Cara-cara yang digunakan bisa berupa tes (pra maupun pasca) yang kemudian melalui berbagai proses uji validitas data

\subsubsection{Sumber Data}

Ada dua jenis sumber data (Arikunto, 2016: 172) dalam penelitian ini, yaitu:

1. Data Primer

Yaitu data yang diperoleh langsung dari responden itu sendiri yaitu konsumen yang membeli mobil pada dealer mobil merek Nissan di Kota Palembang.

2. Data Sekunder

Yaitu data yang terlebih dahulu diperoleh dan dikumpulkan oleh orang lain ataupun dapat juga data yang diperoleh dari internet dan artikel yang berhubungan dengan objek penelitian ( Umar, 2014: 41 ).

\section{5. Populasi dan Sampel Penelitian 3.5.1. Populasi}

Populasi adalah gabungan dari seluruh elemen yang berbentuk peristiwa, hal atau orang yang memiliki karakteristik yang serupa yang menjadi pusat perhatianseorang peneliti karena itu dipandang sebagai sebuah semesta penelitian (Ferdinand, 2014: 60 ). Adapun Populasi dalam penelitian ini adalah seluruh konsumen yang berbelanja di Rumah Makan Sri Melayu di kota Palembang dalam kurun waktu tiga (3) bulan terakhir, yaitu dari bulan Oktober sampai Desember 2020 yang jumlahnya 273 orang.

\subsubsection{Sampel}

Sampel adalah subset dari populasi, terdiri dari beberapa anggota populasi. Teknik pengambilan sampel yang digunakan dalam penelitian ini adalahdengan purposive sampling, yaitu penulis menggunakan pertimbangan sendiri dengancara sengaja dalam memilih anggota populasi yang dianggap dapat memberikaninformasi makanan di Rumah Makan Sri Melayu di kota Palembang dalam kurun waktu 3 bulan terakhir yang berjumlah 273 orang. Jumlah sampel dalam penelitian ditentukan berdasarkan rumus Slovin dikutip oleh Husein Umar (2014:108) adalah sebagai berikut:

Di mana :

$$
\mathrm{n}=\frac{\mathrm{N}}{1+\mathrm{Ne}^{2}}
$$

n : Ukuran Sampel

N : Ukuran Populasi yaitu jumlah total pelanggan PT Bentara Sinergies Multifinance

e : Nilai kritis

$$
\mathrm{n}=\frac{\mathrm{N}}{1+\mathrm{Ne}^{2}}=\frac{273}{1+273\left(0,10^{2}\right)}=72
$$




\subsection{Operasional variabel}

Definisi operasional variabel dari penelitian ini disajikan dalam tabel sebagai berikut:

Tabel 3.1

Definisi Operasional Variabel

\begin{tabular}{|c|c|c|c|c|}
\hline No & Variabel & $\begin{array}{c}\text { Definisi Operasional } \\
\text { Variabel }\end{array}$ & Indikator Penelitian & $\begin{array}{l}\text { Instrumen } \\
\text { Penelitian }\end{array}$ \\
\hline 1 & $\begin{array}{l}\text { Kualitas } \\
\text { produk }\end{array}$ & $\begin{array}{l}\text { Kualitas produk } \\
\text { merupakan keseluruhan } \\
\text { dari ciri produk dalam } \\
\text { kemampuan untuk } \\
\text { memuaskan kebutuhan }\end{array}$ & $\begin{array}{l}\text { 1.Performaatau kinerja produk } \\
\text { 2.Kehandalan produk } \\
\text { 3.Daya tahan produk } \\
\text { 4.Conformance } \\
\text { 5.Kualitas yang dipersepsikan }\end{array}$ & $1-8$ \\
\hline 2 & Citra Merek & $\begin{array}{l}\text { Serangkaian asosiasi } \\
\text { yang dipersepsikan oleh } \\
\text { individu sepanjang waktu } \\
\text { sebagai hasilpengalaman } \\
\text { langsung maupun tidak } \\
\text { langsung terhadap produk }\end{array}$ & $\begin{array}{l}\text { 1.Atribut } \\
\text { 2.Manfaat Fungsional } \\
\text { 3.Manfaat Simbolis } \\
\text { 4.Pengalaman }\end{array}$ & $1-8$ \\
\hline 3 & $\begin{array}{l}\text { Keputusan } \\
\text { Pembelian }\end{array}$ & $\begin{array}{l}\text { Proses dimana } \\
\text { konsumen mengenal } \\
\text { masalahnya, mencari } \\
\text { informasi mengenai } \\
\text { produkatau merektertentu } \\
\text { dan mengevaluasi } \\
\text { seberapa baik masing - } \\
\text { masing alternatif } \\
\text { tersebut dapat } \\
\text { memecahkan masalahnya } \\
\text { yang kemudian mengarah } \\
\text { kepada keputusan } \\
\text { pembelian. }\end{array}$ & $\begin{array}{l}\text { 1.Pengenalanmasalah } \\
\text { 2.Pencarianinformasi. } \\
\text { 3.EvaluasiAlternativ } \\
\text { 4.Keputusanmembeli } \\
\text { 5.Perilakusetelah membeli }\end{array}$ & $1-8$ \\
\hline
\end{tabular}

\subsection{Teknik Analisis Data}

Penelitian ini menggunakan analisis Regresi Berganda dengan pengolahan data menggunakan SPSS 20 for Windows. Adapun tahapan-tahapan Analisis adalah sebagai berikut:

\section{Uji Validitas dan Reliabilitas}

\subsection{Uji Validitas}

Uji validitas digunakan untuk mengukur sah atau valid tidaknya suatu kuesioner. Suatu kuesioner dikatakan valid jika pertanyaan dan kuesioner mampu untuk mengungkap sesuatu yang akan diukur oleh kuesioner tersebut (Ghozali, 2016: 45).

1.2. Uji Reliabilitas
Reliabilitas adalah alat untuk
mengukur suatu kuesioner yang

merupakan indikator dari suatu variabel. Suatu kuesioner dikatakan reliabel atau handal jika jawaban pertanyaan adalah konsisten atau stabil dari waktu ke waktu (Ghozali, 2016: 41). Suatu variabel dikatakan reliabel jika nilai Cronbach Alpha (a) $>0,6$.

\section{Uji Asumsi Klasik}

Uji asumsi klasik yang digunakan dalam penelitian ini adalah:

\section{Uji Normalitas}

Uji Normalitas pada model regresi digunakan untuk menguji apakah nilai residual yang dihasilkan dari regresi terdistribusi secara normal atau tidak. Jika signifikan $>0,05$ maka variabel berdistribusi normal dan sebaliknya, jika signifikan < 0,05 maka variabel tidak berdistribusi 
normal Ghozali dalam Sujarweni (2015:225).

\section{Uji Multikolinieritas}

Uji ini bertujuan untuk menguji suatu model apakah dalam model sebuah regresi ditemukan adanya korelasi antar variabel independen. Adanya multikolinieritas dapat dilihat dari tolerancevalue atau nilai Value Inflation Factor (VIF) melalui program Statistical Package for The Social Sciencefor windows. Batas tolerancevalue adalah 0,1 dan batas VIF adalah 5, dimana :

1. Tolerance Value $<0,1$ atau VIF $>5$ maka terjadi multikolinieritas.

2. Tolerance Valie $>0,1$ atau $\mathrm{VIF}>5$ maka tidak terjadi multikolinieritas

\section{Uji Heteroskedastisitas}

Uji ini dilakukan untuk menguji apakah dalam sebuah model regresi terjadi ketidak samaan varians dari residual suatu pengamatan kepengamatan lain. Jika varians dari residual atau dari suatu pengamatan kepengamatan yang lain tetap, maka disebut homoskedastisitas, dan jika varians berbeda maka disebut heteroskedastisitas.

\section{Analisis Regresi Linier Berganda}

Analisis Regresi Linier Berganda bertujuan untuk mengetahui pengaruh kualitas produk dan citra merek terhadapkeputusan pembelian konsumen pada rumah makan Sri Melayu di kota Palembang. Persamaan regresi dalam penelitian ini adalah:

$\mathbf{Y}=\mathbf{a}+\mathbf{b}_{1} \mathbf{X}_{1}+\mathbf{b}_{2} \mathbf{X}_{2}+\mathbf{e}$

Keterangan:

$\mathrm{Y}=$ Keputusan Pembelian

$\mathrm{a}=$ Konstanta $b_{1}=$ Koefisien regresi variabel kualitas produk

$\mathrm{X}_{1}=$ kualitas produk

$\mathrm{b}_{2}=$ Koefisien regresi variabel citra merek

$\mathrm{X}_{2}=$ citra merek

\section{Pengujian Hipotesis}

1. Uji Parsial (Uji t)

Uji $\mathrm{t}$ digunakan untuk menguji signifikansi hubungan antara variabel $\mathrm{X}$ dan $\mathrm{Y}$, apakah variabel X1, X2, X3, X4, $\mathrm{X} 5$ benar-benar berpengaruh terhadap variabel $\mathrm{Y}$ secara terpisah atau parsial (Ghozali, $2016: 88$ ).

\section{Uji F}

Dalam penelitian ini, uji $F$ digunakan untuk mengetahui tingkat siginifikansi pengaruh variabel-variabel independen secara bersama-sama (simultan) terhadap variabel dependen (Ghozali 2016:89)

\section{Koefisien Determinasi $\left(\mathrm{R}^{2}\right)$}

Koefisien determinasi $\left(\mathrm{R}^{2}\right)$ pada intinya mengukur seberapa jauh kemampuan model dalam menerangkan variasi varabel terikat. Nilai koefisien determinasi adalah antar nol dan satu( $\left.0<\mathrm{R}^{2}<1\right)$. Nilai $\mathrm{R}^{2}$ yang kecil berarti kemampuan variabel independen dalam menjelaskan variasi variabel dependen amat terbatas.

\section{HASIL PENELITIAN DAN PEMBAHASAN}

\subsection{Analisis data}

\subsubsection{Uji Validitas}

Suatu kuesioner dikatakan valid jika pertanyaan dan kuesioner mampu untuk mengungkap sesuatu yang akan diukur oleh kuesioner tersebut (Ghozali, 2016: 45).

Tabel 4.1

Hasil Uji Validitas

\begin{tabular}{|l|c|l|c|c|c|}
\hline No & Variabel & Butir Pertanyaan & r hitung & r tabel & Keterangan \\
\hline \multirow{2}{*}{1} & \multirow{2}{*}{ Kualitas Produk } & P1 & 0.599 & 0.231 & Valid \\
\cline { 3 - 6 } & & P2 & 0.699 & 0.231 & Valid \\
\cline { 3 - 6 } & & P3 & 0.691 & 0.231 & Valid \\
\hline
\end{tabular}




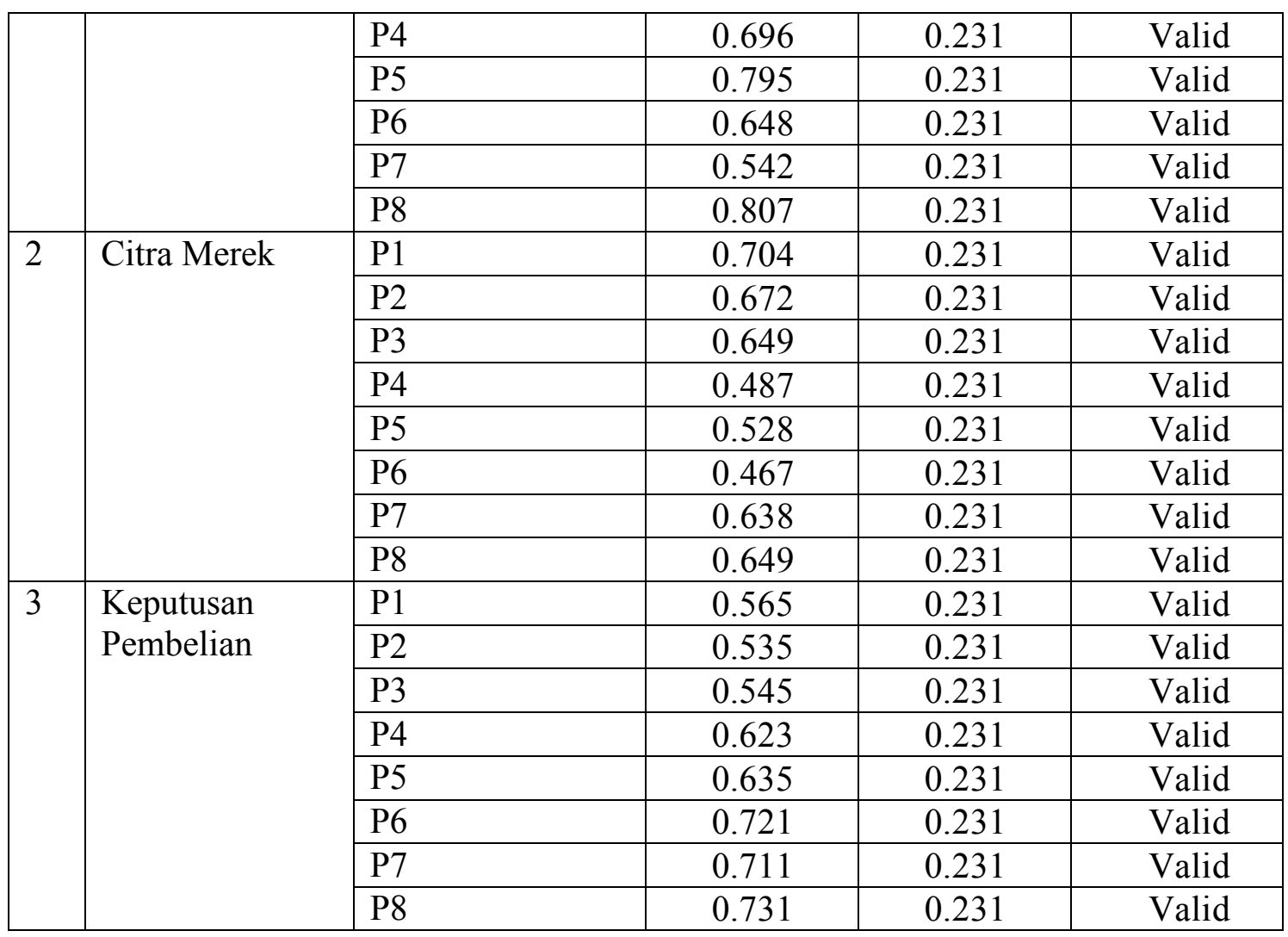

\subsubsection{Uji Reliabilitas}

Suatu kuesioner dikatakan reliabel atau handal jika jawaban pertanyaan adalah konsisten atau stabil dari waktu ke waktu (Ghozali, 2016: 41). Suatu variabel dikatakan reliabel jika nilai Cronbach Alpha (a) $>0,6$.

Tabel 4.2

Hasil Uji Relibilitas

\begin{tabular}{|l|l|c|r|l|}
\hline No & \multicolumn{1}{|c|}{ Variabel } & C.R & Standar & \multicolumn{1}{|c|}{ Keterangan } \\
\hline 1 & Kualitas Produk & 0,872 & 0.600 & Reliabel \\
\hline 2 & Citra merek & 0,796 & 0.600 & Reliabel \\
\hline 3 & Keputusan Pembelian & 0,826 & 0.600 & Reliabel \\
\hline
\end{tabular}

Ketentuan reliabilitas yang ditentukan dari skala Cronbach Alpha (C.R) pada tabel 4.2 $1 \mathrm{ebih}$ dari 0,6 berarti semua reliabilitas variabel dalam penelitian ini sangat reliabel.

\subsubsection{Uji Asumsi Klasik}

\section{UjiNormalitas}

a. Dengan grafik histogram

Hasil uji normalisasi data dengan melihat histogram sebaran data yang disajikan sebagai berikut: 


\section{Gambar 2 \\ Grafik Histogram}

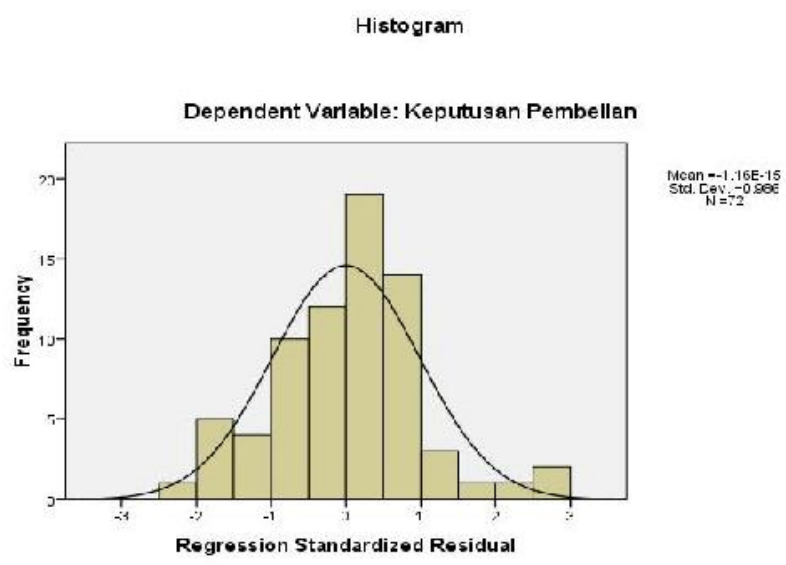

Berdasarkan tampilan gambar di atas, dapat dilihat bahwa dari grafik histogram yang berbentuk lonceng, grafik tersebut tidak miring kesamping kiri maupun kanan yang artinya adalah data berdistribusi normal.

b. GrafikP-Plot

Berikut inidapat dilihat data menyebar disekitar garis diagonal seperti pada gambar berikut:

\section{Gambar 3}

Grafik PP-Plot

Normal P-P Plot of Regression Standardized Residual

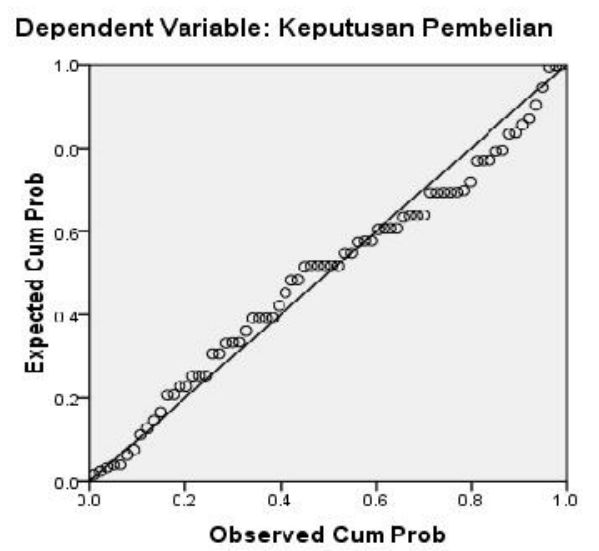

\section{Uji Heteroskedastisitas}

Uji heterokedastisitas digunakan untuk menguji apakah dalam model regresi terjadi ketidaksamaan varians dari residual pada satu pengamatan ke pengamatan yang lain, seperti terlihat pada gambar berikut ini 


\section{Gambar 4.}

\section{Grafik Scatter Plot}

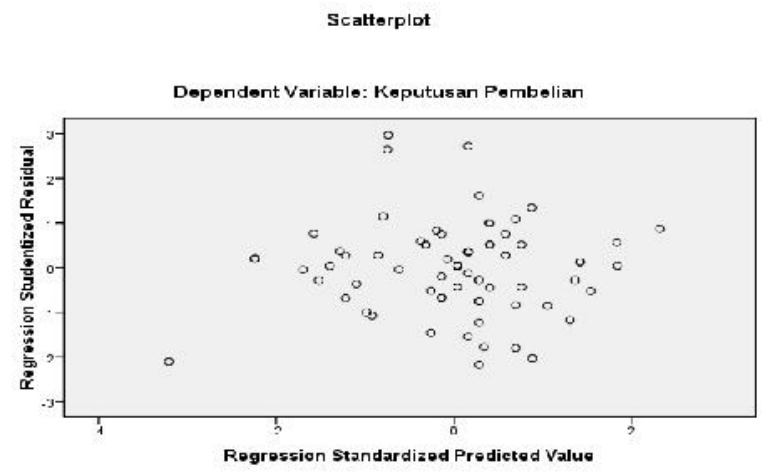

Pada diagram pencar diatas menunjukkan pada model regresilinear berganda tidak terdapat heteroskedastisitas.

\section{Uji Multikolinieritas}

Untuk mendeteksi adatidaknyagejalamultikolinearitas maka dilakukan dengan melihat VarianceInflation Factor (VIF), bila nila VIF lebih kecil dari 10 maka tidak terjadi multikolinieritas.

Tabel4.3

Uji Multikolinieritas

\begin{tabular}{|l|c|l|}
\hline Variabel & VIF & Keterangan \\
\hline $\mathrm{X} 1$ & 0,318 & NonMultikolinieritas \\
\hline $\mathrm{X} 2$ & 0,318 & NonMultikolinieritas \\
\hline
\end{tabular}

Berdasarkan Tabel 6 diketahui bahwa diantara variabel-variabel bebas yang digunakan mempunyai nilai VIF lebih kecil dari 10, dari hasil tersebut dapat disimpulkan bahwa model regresi linier tersebut bebas dari multikolinearitas atau tidak terjadi korelasi diantara satu dengan yang lain.

\subsubsection{Uji Analisis Regresi Berganda}

Perhitungan regresi linier berganda digunakan untuk memprediksi besarnya hubungan antara variabel terikat (dependen), dengan variabel bebas (independen).

\section{Tabel 4.4}

Hasil Uji Analisis Regresi Berganda

Coefficients $^{\mathrm{a}}$

\begin{tabular}{|c|c|c|c|c|c|}
\hline \multirow{2}{*}{ Model } & \multicolumn{2}{|c|}{$\begin{array}{l}\text { Unstandardized } \\
\text { Coefficients }\end{array}$} & \multirow{2}{*}{$\begin{array}{c}\begin{array}{c}\text { Standardized } \\
\text { Coefficients }\end{array} \\
\text { Beta }\end{array}$} & \multirow[b]{2}{*}{$\mathrm{t}$} & \multirow[b]{2}{*}{ sig } \\
\hline & B & Std.Error & & & \\
\hline $\begin{array}{l}1 \quad \text { (Constant) } \\
\text { Kualitas Produk } \\
\text { Citra merek }\end{array}$ & $\begin{array}{r}5.427 \\
.479 \\
.396\end{array}$ & $\begin{array}{r}2.535 \\
.153 \\
.218\end{array}$ & $\begin{array}{l}.418 \\
.385\end{array}$ & $\begin{array}{rr} & 2.280 \\
& 3.121 \\
2.437 & \end{array}$ & $\begin{array}{l}.000 \\
.001 \\
.004\end{array}$ \\
\hline
\end{tabular}

Modelpersamaanregresiyang dapatdituliskandarihasiltersebutdalam bentuk persamaan regresisebagai berikut : $\mathrm{Y}=5,427+0,479 \mathrm{X} 1+0,396 \mathrm{X} 2$ 


\subsubsection{Uji Hipotesis}

1. Uji Signifikan Simultan (Uji-f)

Hasil pengujian hipotesis $\mathrm{F}$ dapat dilihat pada tabel berikut:

Tabel.4.5

Hasil uji F

\begin{tabular}{|c|c|c|c|c|c|c|}
\hline \multicolumn{7}{|c|}{ ANNOVA } \\
\hline & Model & $\begin{array}{l}\text { Sumof } \\
\text { Squares }\end{array}$ & Df & MeanSquare & $\mathrm{F}$ & Sig. \\
\hline \multirow[t]{3}{*}{1} & Regression & 537.516 & 2 & 273.753 & 60.211 & $.000^{\mathrm{a}}$ \\
\hline & Residual & 323.762 & 69 & 4.547 & & \\
\hline & Total & 681.218 & 71 & & & \\
\hline
\end{tabular}

Karena nilai $\mathrm{F}$ hitung 60, 211 lebih besar dari nilai $\mathrm{F}$ tabel 3,13 maka dapat ditarik kesimpulan bahwa variabel bebas $\mathrm{X}_{1}$ dan $\mathrm{X}_{2}$ secara simultan berpengaruh terhadap variabel terikat (Y).

\section{UjiSignifikasiParsial(Uji-t)}

Dari hasil Uji t dari tabel 4.4 secara rinci dapat dijelaskan sebagai berikut:

- Kualitas produk (X1) terhadap keputusan pembelian (Y) Untuk variabel kualitas produk (X1) memiliki nilai signifikansi 0,00. Nilai Sigt $<5 \%(0,000<0,05)$. Dengan demikian kualitas produk (X1) berpengaruh signifikan terhadap keputusan pembelian (Y).

- Citra merek (X2) terhadap keputusan pembelian (Y) Untuk variabel citra merek (X2) memiliki nilai signifikansi 0,000 . Nilai Sig $t<5 \%(0,001<0,05)$. Dengan demikian citra merek (X2) berpengaruh signifikan terhadap keputusan pembelian (Y).

\section{Uji KoefisienKorelasi(R)danDeterminasi $\left(\mathbf{R}^{\mathbf{2}}\right)$}

Tabel 4.6

Hasil Uji Determinasi

Model Summary ${ }^{\mathrm{D}}$

\begin{tabular}{|l|r|r|r|r|r|}
\hline Model & $\mathrm{R}$ & R Square & $\begin{array}{c}\text { Adjusted R } \\
\text { Square }\end{array}$ & $\begin{array}{c}\text { Std. Error of the } \\
\text { Estimate }\end{array}$ & Durbin-Watson \\
\hline 1 & $.779^{\mathrm{a}}$ & .606 & .287 & 2.06077 & 1.603 \\
\hline
\end{tabular}

Berdasarkan tabel 4.6 dapat diketahui bahwa koefisien determinasi $\left(\mathrm{R}^{2}\right)$ sebesar 0,606 atau $60,6 \%$.

\section{KESIMPULAN DAN SARAN}

\subsection{Kesimpulan}

Dari rumusan masalah penelitian yang diajukan, maka analisis data yang telah dilakukan dan pembahasan yang telah dikemukakan pada bab sebelumnya, dapat ditarik beberapa kesimpulan dari penelitian ini adalah sebagai berikut :
1. Berdasarkan analisis secara parsial, ternyata hasil penelitian membuktikan bahwa semua variabel independen (kualitas produk dan citra merek) mempunyai pengaruh positif terhadap variabel dependen yaitu keputusan pembelian konsumen pad Rumah Makan Sri Melayu di Kota Palembang. Artinya menurut 
konsumen variabel independen tersebut dianggap penting ketika akan membeli dan makan di ruman makan Sri Melayu.

2. Berdasarkan pengujian secara simultan, ternyata hasil penelitian membuktikan bahwa semua variabel independen (kualitas produk dan citra merek) secara simultan mempunyai pengaruh yang signifikan terhadap variabel dependen yaitu keputusan pembelian.

3. Hasil pengujian regresi berganda menunjukkan bahwa semua variabel independen (kualitas produk dan citra merek) berpengaruh positif terhadap keputusan pembelian. Pengaruh positif terbesar terhadap keputusan pembelian adalah pada variabel Kualitas Produk(X1) hal ini ditunjukkan dari nilai koefisien regresi sebesar 0,479 .

\subsection{Saran}

Berdasarkan kesimpulan yang diperoleh dalam penelitian ini, maka diajukan saran-saran sebagai pelengkap terhadap hasil penelitian yang dapat diberikan sebagai berikut :

1. Dalam rangka meningkatkan kualitas produk sebaiknya Sri Melayu melakukan peninjauan kembali pada beberapa produk yang kurang diminati konsumen. Dan untuk meningkatkan citra merek Sri Melayu harus lebih mempromosikan produk handalan mereka secara berulang-ulang agar tertanam di fikiran konsumen bahwa Sri Melayu merupakan rumah makan dengan kuliner khas Palembang terbaik.

2. Untuk meningkatkan keputusan pembelian sebaiknya Sri Melayu lebih banyak lagi melakukan promosi, Sri Melayu harus menginformasikan kepada pelanggan tentang produk- produk andalan yang dimiliki agar tidak kalah bersaing dengan produk sejenis.

3. Untuk penelitian yang akan datang, disarankan untuk menambah variabel independen lainnya selain kualitas produk dan citra merek yang tentunya dapat mempengaruhi variabel dependen keputusan pembelian agar lebih melengkapi penelitian ini karena masih ada variabel-variabel independen lain di luar penelitian ini yang mungkin bisa mempengaruhi keputusan pembelian.

\section{DAFTAR PUSTAKA}

Adisaputro Gunawan, (2017). Manajemen Pemasaran Edisi Pertama Unit Penerbitan dan Percetakan Sekolah Tinggi Ilmu Manajemen YKPN, Yogyakarta

Arikunto Suharsimi (2016) Prosedur

Penelitian Suatu Pendekatan

Praktik PT Rineka Cipta Jakarta

Assauri Sofjan, (2017) Manajemen Produksi dan Operasi Edisi Revisi Fakultas Ekonomi Universitas Indonesia

Eka Dessy Mardiastorini, (2018) Pengaruh Kualitas Produk dan Citra Merek Terhadap Keputusan Pembelian Produk Benih Jagung Bisi. Skripsi Fakultas Ekonomi dan Bisnis UNDIP.

Fandy Tjiptono, (2019). Strategi Pemasaran Edisi III, Penerbit Andi, Yogyakarta

Farid Yuniar Nugroho, (2011), Pengaruh Citra Merek dan Kepuasan Pelanggan terhadap Loyalitas Konsumen Yogyakarta Fakultas Pertanian Universitas Pembangunan Nasional Veteran.

Ferdinand, Augusty (2014), Metode Penelitian Manajemen Edisi 2, 
Badan Penerbit Universitas Diponegoro, Semarang

Ghozali Imam, (2016). Aplikasi Analisis Multivariate Dengan Program SPSS Universitas Diponegoro, Jakarta..

Kotler, Philip and Garry Amstrong (2016). Principles of marketing. New Jersey: Person education Limited.

Kotler dan Keller, (2019). Manajemen Pemasaran Edisi Kedua Belas Jilid 2 PT Indeks, Jakarta..

Mudrajat Kuncoro, (2014). Metode Riset Untuk Bisnis \& Ekonomi Bagaimana Meneliti \& Menulis Tesis Edisi 3 Penerbit Airlangga, Jakarta.

S Jordanus Saleh (2017), Pengaruh Citra Merek dan Kualitas Produk terhadap Keputusan Pembelian Sepatu Merek Vans Fakultas Ekonomi Universitas Brawijaya

Schiffman, Leon G, dan Leslie Lazar Kanuk. (2010). Customer Behavior Edisi Ke sepuluh. New Jersey: Prentice Hall

Sinta Septiana (2016) Pengaruh Citra Merek dan Kualitas Produk Terhadap Keputusan Pembelian Konsumen Pada Sabun Mandi Cair Merek Dettol di Bandar Lampung Skripsi Fakultas Ekonomi UNILA.

Sekaran, Uma dan Bougie R (2017) Metode Penelitian untuk Bisnis Pendekatan Pengembangan keahlian Salemba empat Jakarta

Sujarweni, Wiratna (2015), SPSS untuk Penelitian, Pustaka Baru Press Jakarta

Umar, H (2014). Metode Penelitian untuk Skripsi dan Tesis Bisnis. PT. Raja Grafindo Perkasa, Jakarta. 